\title{
'September Sun' Seaside Alder: An Autumn-blooming Shrub Native to North America
}

\section{William R. Graves ${ }^{1}$ and James A. Schrader \\ Department of Horticulture, Iowa State University, Ames, IA 50011-1100}

Additional index words. Alnus maritima subsp. oklahomensis, actinorhizal plants, symbiotic nitrogen fixation, Oklahoma alder, wetlands, native species, rare species, new cultivar name

\begin{abstract}
'September Sun' is the first cultivar selected from seaside alder [Alnus maritima (Marsh.) Muhl. ex Nutt.], a rare species that occurs as three disjunct subspecies separated from one another by over $1000 \mathrm{~km}$ (Schrader and Graves, 2002). As a genotype of A. maritima subsp. oklahomensis Schrader \& Graves, 'September Sun' exhibits the traits of its subspecies that distinguish it from Alnus maritima subsp.

Received for publication 17 Mar. 2003. Accepted for publication 26 July 2003. We thank the Iowa Nursery and Landscape Research Corporation, the J. Frank Schmidt Family Charitable Trust, and the Landscape Plant Development Center for their support of this work. Journal paper of the Iowa Agriculture and Home Economics Expt. Station, Ames, and supported by the Hatch Act and State of Iowa funds.

${ }^{1}$ To whom reprint requests should be addressed. E-mail: graves@iastate.edu.
\end{abstract}

georgiensis Schrader \& Graves and Alnus maritima subsp. maritima. Schrader and Graves (2002) provided a diagnostic key for the three subspecies.

Plants of 'September Sun' are suitable for use in USDA hardiness zone 4a and possibly in areas as cold as USDA zone $3 \mathrm{a}$ (Schrader and Graves, 2003). Although the heat tolerance and minimal chilling requirement of this cultivar have not been established, it is native to USDA zone 7a. Therefore, its useful range includes areas with mean annual minimum temperatures at least as mild as $-15^{\circ} \mathrm{C}$, and attempts to use 'September Sun' in somewhat milder climates are warranted. 'September Sun' thrives in wet soils, can survive complete inundation of its root zone with fresh water indefinitely, and is more resistant to drought than are other alders cultivated in North America (Gardner, 2001). Indigenous plants of A. maritima subsp. oklahomensis are found at sites where shade during photoperiods averages only 29\% (Schrader and Graves, 2002). This fact, along with our observations of plants in greenhouses and field trials, indicates that 'September Sun' should be planted at exposed sites only. Its symbiotic relationship with Frankia, a ubiquitous, nitrogen-fixing soil bacterium, make 'September Sun' an excellent choice for nitrogen-poor soils (Benson and Sylvester, 1993; Kratsch and Graves, 2004). Soil pH is as high as 8.4 adjacent to indigenous A. maritima subsp.oklahomensis in Oklahoma (Schrader and Graves, 2002), and we have grown vigorous plants of 'September Sun' that remain free of foliar chlorosis in soils with $\mathrm{pH}$ exceeding 7 in Iowa.

\section{Origin}

'September Sun' was selected from a trial of seedlings of A. maritima subsp. oklahomensis on the campus of Iowa State Univ., Ames. The seed that formed the original plant was obtained from an open-pollinated A. maritima subsp. oklahomensis growing on the bank of the Blue River near Tishomingo, Okla. (lat. $34^{\circ} 19^{\prime} 38^{\prime \prime} \mathrm{N}$, long. $96^{\circ} 35^{\prime} 25^{\prime \prime} \mathrm{W}$ ). 'September Sun' has been propagated with high rates of success from softwood cuttings by using the methods of Schrader and Graves (2000b). Ramets grow rapidly and can be $2 \mathrm{~m}$ tall within 2 years.

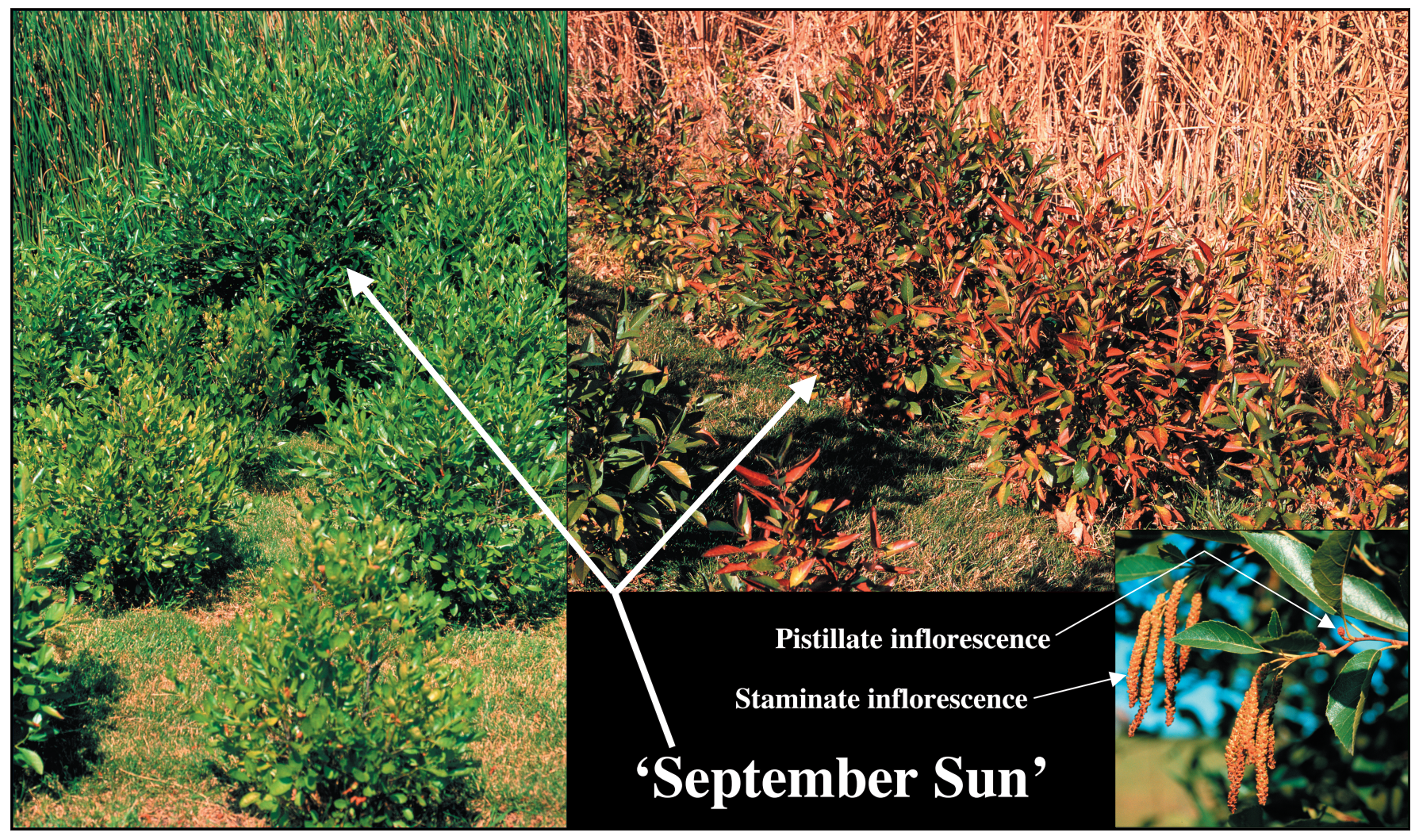

Fig. 1. The original 'September Sun' growing on the campus of Iowa State Univ., Ames. The left image shows the plant on 10 Aug. 2000, near the end of its third season of development from a seed. The main image to the right depicts 'September Sun' on 1 Nov. 1999, when autumnal leaf coloration was evident. Both of these images show other, slower-growing genotypes of Alnus maritima subsp. oklahomensis that were propagated from seed and planted in the field at the same time as 'September Sun'. The inset to the lower right shows staminate and pistillate inflorescences of 'September Sun' on 24 Sept. 2002 near Ames, Iowa. 
Table 1. Trunk diameter, canopy height, and canopy volume of the original plant of 'September Sun' after three growing seasons in a trial in Ames, Iowa. Data for 'September Sun' are compared with data from half-sibling plants of three maternal parents of Alnus maritima subsp. oklahomensis. Plants of Blue River \#6 were half-siblings of 'September Sun' (propagated from seed of the same maternal tree). Pennington \#5 and \#6 were half-sibling groups from a separate subpopulation of subsp. oklahomensis (see Schrader and Graves, 2002).

\begin{tabular}{lccc}
\hline Genotype & $\begin{array}{c}\text { Trunk diam } \\
(\mathrm{mm})\end{array}$ & $\begin{array}{c}\text { Canopy ht } \\
(\mathrm{cm})\end{array}$ & $\begin{array}{c}\text { Canopy vol } \\
\left(\mathrm{m}^{\mathrm{y}}\right)\end{array}$ \\
\hline 'September Sun' & $30.8 \mathrm{a}^{\mathrm{w}}$ & $238.9 \mathrm{a}$ & $6.17 \mathrm{a}$ \\
Blue River \#6 & $23.0 \mathrm{ab}$ & $166.3 \mathrm{~b}$ & $2.35 \mathrm{~b}$ \\
Pennington \#5 & $24.0 \mathrm{ab}$ & $155.1 \mathrm{~b}$ & $1.72 \mathrm{bc}$ \\
Pennington \#6 & $19.9 \mathrm{~b}$ & $142.1 \mathrm{~b}$ & $1.16 \mathrm{c}$ \\
\hline
\end{tabular}

${ }^{2}$ Diameter of the largest trunk at $10 \mathrm{~cm}$ above the soil surface.

yistance from the soil surface to the apex of the tallest shoot.

${ }^{x}$ Canopy volume was calculated by multiplying the shoot height by the horizontal canopy area (area of an ellipse calculated from the north-south and east-west canopy diameter measurements).

${ }^{w}$ Means within each column followed by the same letter are not significantly different at $P \leq 0.05$ according Student's $t$ test. $N=1$ for 'September Sun', $N=8$ for Blue River \#6 and Pennington \#5, N = 10 for Pennington \#6. Dunnett's test for comparing treatment groups against a control (Stevens, 1990) was used to confirm differences between 'September Sun' and the three half-sibling groups.

\section{Description}

Mature plants of 'September Sun' are large shrubs or small trees with multiple trunks that form broadly rounded, upright canopies $7 \mathrm{~m}$ tall and $5 \mathrm{~m}$ wide. As a genotype of A. maritima subsp. oklahomensis, trunks of 'September Sun' support more leaves and axillary shoots than are found on plants of the other subspecies (Schrader and Graves, 2000a). This leads to dense canopies of glossy leaves that are darker green than the leaves of all other alders indigenous to North America (Furlow, 1979). Unlike some other A. maritima we have observed, leaves of 'September Sun' display mottled blends of yellow, orange, and rich brown under autumnal conditions in USDA hardiness zone 5a (Fig. 1). Alnus maritima is monoecious and is the only species of alder native to North America that blooms late in the growing season. Yellow, pendulous catkins expand to $8 \mathrm{~cm}$ long and display staminate flowers from mid-August to late September
(Fig. 1). The catkins occur in clusters of two to six at tips of most branches, providing color in the landscape after flowering has ceased on most other trees and shrubs, and before leaf coloration begins during autumn. Pistillate inflorescences are 3 to $5 \mathrm{~mm}$ in diameter and pink (Fig. 1). They occur on peduncles that arise from nodes immediately basipetal to the staminate inflorescences. The infructescences of 'September Sun' are medium to dark brown, cone-like strobili; each is 16 to $22 \mathrm{~mm}$ long and 11 to $14 \mathrm{~mm}$ in diameter. Strobili mature 1 year after pollination and then persist on the branches through at least one more season, providing subtle ornamental appeal throughout the year.

This cultivar differs from other genotypes of its species as the fastest-growing, most densely foliated, and most symmetrically shaped individual we have observed in field trials with over 1000 plants (Fig. 1). During a trial that lasted three growing seasons at a site in Ames, Iowa, 'September Sun' grew larger
(Table 1) and developed a more symmetrical canopy shape than did other seedlings of Alnus maritima subsp. oklahomensis, including halfsiblings of the original 'September Sun'.

A herbarium specimen [16 June 2003, $J$. Schrader 123 (ISC!)] has been deposited at the Ada Hayden Herbarium(ISC), Iowa State Univ. A photograph and a herbarium specimen showing reproductive structures have been provided to the Brooklyn Botanical Garden.

\section{Availability}

'September Sun' has been propagated at Iowa State Univ. and is being distributed to nurseries. Contact the authors to request rooted stem cuttings or for a list of commercial sources.

\section{Literature Cited}

Benson, D.R. and W.B. Sylvester. 1993. Biology of Frankia strains, actinomycete symbionts of actinorhizal plants. Microbiol. Rev. 57:293-319.

Furlow, J.J. 1979. The systematics of the American species of Alnus (Betulaceae). Rhodora 81: $1-121,151-248$.

Gardner, S.J. 2001. Plant development and gas exchange of Alnus maritima in dry and flooded soil. MS Thesis, Iowa State Univ., Ames.

Kratsch,H.A. and W.R. Graves. 2004. Ultrastructure of nodules from Alnus maritima. Acta Hort. (in press).

Schrader, J.A. and W.R. Graves. 2000a. Seed germination and seedling growth of Alnus maritima from its three disjunct populations. J. Amer. Soc. Hort. Sci. 125:128-134.

Schrader, J.A. and W.R. Graves. 2000b. Propagation of Alnus maritima from softwood cuttings. HortScience 35:293-295.

Schrader, J.A. and W.R. Graves. 2002. Infraspecific systematics of Alnus maritima (Betulaceae) from three widely disjunct provenances. Castanea 67 : 380-401.

Schrader, J.A. and W.R. Graves. 2003. Phenology and depth of cold acclimation in the three subspecies of Alnus maritima. J. Amer. Soc. Hort. Sci. 128:330-336.

Stevens, J.P. 1990. Intermediate statistics: A modern approach. Lawrence Erlbaum Assoc., Hillsdale, N.J. 